\title{
Biological traits of Cyzicus grubei (Crustacea, Spinicaudata, Cyzicidae) in south-western Iberian Peninsula
}

\author{
José Luis Pérez-Bote, Juan Pablo González Píriz and Alejandro Galeano Solís \\ Zoology Section, Faculty of Sciences, University of Extremadura, Badajoz, Spain. \\ * Corresponding author: jlperezbote.university@gmail.com
}

Received: 10/01/2014

Accepted: 12/05/2014

\begin{abstract}
Biological traits of Cyzicus grubei (Crustacea, Spinicaudata, Cyzicidae) in south-western Iberian Peninsula

In this study, characteristics of the biology of the spinicaudatan Cyzicus grubei were determined from a population in a temporary pond in the south-western Iberian Peninsula from January 2011 to July 2011. The results indicated the existence of a single cohort for the duration of the flooding period. Non-ovigerous females and males were present in the pond throughout the study period. However, ovigerous females were present from mid-April to early July. Males had valves significantly larger and higher than females. The relationship between the valve length and the valve height showed positive allometry in males and negative allometry in females and the whole population (mature and immature individuals). The smallest mature male was $8.13 \mathrm{~mm}$ in valve length, whereas the smallest ovigerous female was $8.21 \mathrm{~mm}$ in valve length. Females outnumbered males in winter and early spring, and males were more abundant in late spring and early summer. The mean number of eggs on ovigerous females was $574.74 \pm 245.29$, ranging from 241 to 1068 eggs/female. The number of eggs was linearly correlated with the valve length of the female.
\end{abstract}

Key words: Population dynamics, body size, relative growth, sex ratio, Cyzicus.

\section{RESUMEN}

Características biológicas de Cyzicus grubei (Crustacea, Spinicaudata, Cyzicidae) en el suroeste de la península Ibérica

Se han estudiado algunos aspectos de la biología del espinicaudado Cyzicus grubei en una población localizada en el suroeste de la península Ibérica, desde enero hasta julio de 2011. Se pudo constatar la presencia de una sola cohorte durante todo el periodo de estudio, estando presente los machos y las hembras no ovígeras durante todo el periodo de inundación, mientras que las hembras ovígeras solo se detectaron desde mediados de abril hasta principios de julio. Los machos presentaron valvas significativamente más altas y anchas que las hembras, detectándose en aquellos una correlación positiva entre la longitud y la anchura de las valvas, mientas que en las hembras y en el conjunto de la población (individuos maduros y no maduros) la correlación fue negativa. El tamaño del menor macho maduro fue de $8.13 \mathrm{~mm}$, mientras que la menor hembra ovígera alcanzó una longitud de $8.21 \mathrm{~mm}$. Las hembras fueron más numerosas que los machos en invierno y principios de primavera, sin embargo éstos son más abundantes a finales de primavera y principios de verano. El número medio de huevos por hembra fue de $574.74 \pm 245.29$, oscilando entre 241 y 1068 huevos por hembra, apreciándose una relación positivas entre el número de huevos y la longitud de las valvas de la hembras.

Palabras clave: Dinámica poblacional, tamaño corporal, crecimiento relativo, sex ratio, Cyzicus.

\section{INTRODUCTION}

The large Branchiopoda, comprised of fairy shrimps (Anostraca), tadpole shrimps (Notostra- ca) and clam shrimps (Spinicaudata), are emblematic and phylogenetically old members of the resident community of temporary waters that are sensitive to climate change (Pyke, 2005). 
In the Iberian Peninsula, the Cyzicidae are represented by only two species: Cyzicus grubei and C. tetracerus (Alonso, 1996). Cyzicus grubei (Simon, 1886) is a species endemic to the Iberian Peninsula (Brtek \& Thiéry, 1995; Alonso, 1996) and the Balearic Islands (Alonso, 1996). In the Balearics, it has been found in only one temporary pond on Minorca Island. However, on the Iberian Peninsula, $C$. grubei has been found in the Douro, Tagus, Guadalquivir (Alonso, 1996), and Guadiana (Pérez-Bote, 2001, 2004) basins and in the south of Portugal (Machado et al., 1999b).

Until quite recently, little was known about the genetics, life history, or behaviour of C. grubei in Iberian ponds. Previously, Alonso (1996) provided basic information on the biology of this species in some temporary ponds of Central Spain. Subsequently, Machado et al. (1999a) and Pérez-Bote et al. (2004) reported new biological data on this species in the south-west Iberian Peninsula.

Species of Cyzicus may be used as bioindicators of environmental quality and climate change (Pyke, 2005). Therefore, it is extremely important to study the life cycle of these species, especially the population dynamics in their natural habitat and their conservation in freshwater environments, in the Iberian Peninsula and in other areas of the world where these and similar species occur. In this paper, data on several aspects of the biology of $C$. grubei are reported: morphometrics, population dynamics, relative growth, and egg production. These data provide basic knowledge that can be useful in further examinations of the biology and ecology of these crustaceans.

\section{MATERIALS AND METHODS}

\section{Site of study and sampling of the branchiopods}

La Gitanilla pond is located in a grain-producing plain $\left(38^{\circ} 39^{\prime} \mathrm{N}, 5^{\circ} 16^{\prime} \mathrm{W}\right.$; Extremadura, Spain, Fig. 1), which also includes patches of Mediterranean forest (Quercus rotundifolia Lamarck, 1875). The pond is located near the Complejo Lagunar de la Albuera (RAMSAR site and special protection area for birds). La Gitanilla is an ephemeral pond of endorheic character with

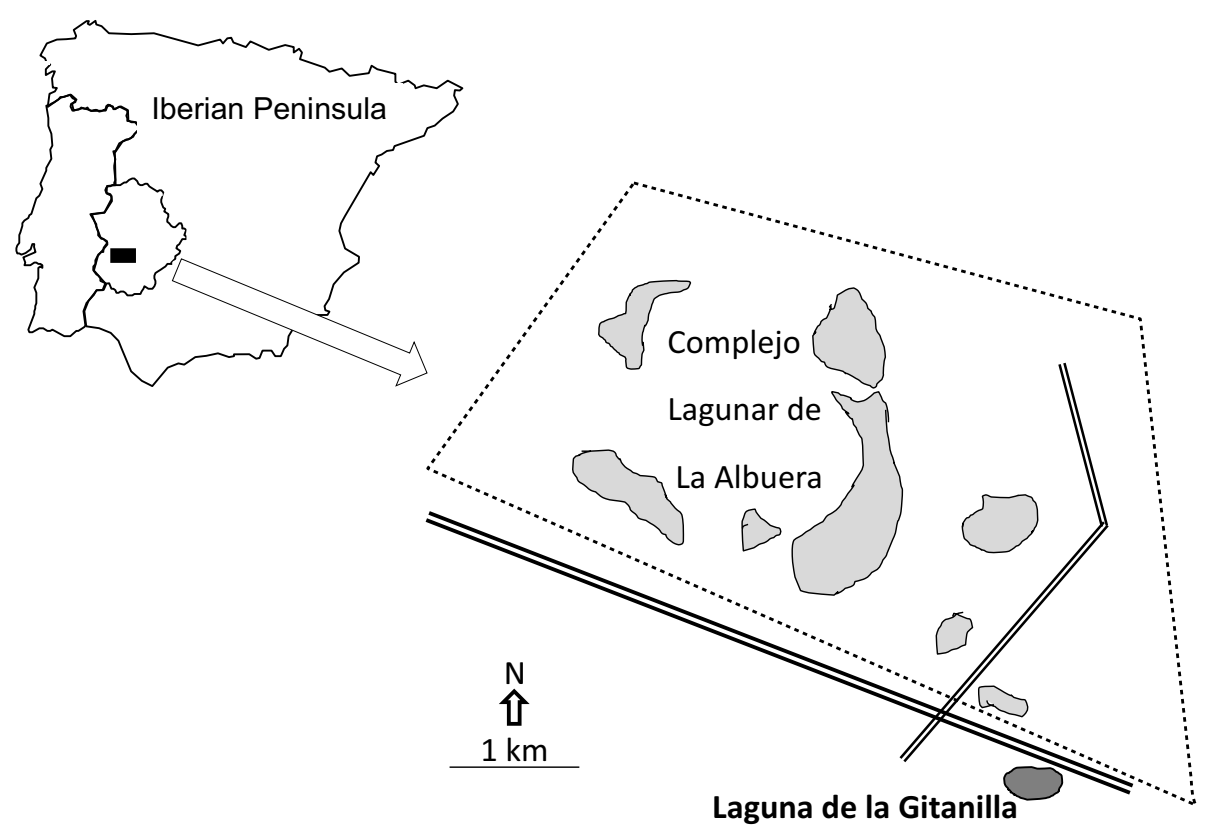

Figure 1. Localisation of La Gitanilla pond. Localización de la laguna de La Gitanilla. 
a surface area of 13,400 $\mathrm{m}^{2}$ (diameter: $154 \mathrm{~m}$; maximum depth: $0.61 \mathrm{~m}$ ), whose margin is protected by a ring of vegetation (breadth: 2-7 m) composed exclusively of Eryngium corniculatum (Umbelliferae) (Lamarck, 1875). There are two clearly distinguishable areas in the pond, with respect to depth and substrate: a central area (approximately $0.30-0.60 \mathrm{~m}$ depth, silt and clay) and a peripheral area (less than $<0.30 \mathrm{~m}$ depth, sand and gravel). The animal community of the pond is dominated by insects (25 species), followed by crustaceans (10 species), and amphibians (4 species) (Pérez-Bote et al., 2008). The climate is Mediterranean with a clear Atlantic influence, with hot dry summers (air maximum temperature: $46^{\circ} \mathrm{C}$ ) and cool rainy winters. The annual rainfall is less than $300 \mathrm{~mm}$, with the maximum rainfall period in February and March, and the minimum in July and August. The pond's hydrological cycle is very irregular and depends completely on the periods of rain. Normally, water is maintained from October-November to June-July. Water parameters during the study period $(n=11) \quad($ mean \pm S.D., minimum and maximum values) were: water temperature $\left({ }^{\circ} \mathrm{C}\right)$ : $15.10 \pm 4.02(10.3-22.8)$; conductivity $(\mu \mathrm{S} / \mathrm{cm})$ : $327.63 \pm 172.28$ (130-715); dissolved oxygen (mg/l): $7.89 \pm 1.88$ (5.22-1.16); and $\mathrm{pH}: 7.15$ \pm 0.37 (6.51-7.80).

C. grubei were sampled bimonthly, from January to July 2011, on the shores of La Gitanilla pond (the pond remained unfilled to the end of December 2010). Specimens were captured during the daytime using a $200 \mu \mathrm{m}$ mesh D-frame pond net ( $20 \mathrm{~cm}$ in diameter), which was dragged from the centre of the pond to the bank, approximately $5 \mathrm{~cm}$ above the bottom. Sampling was performed during a $20 \mathrm{~min}$ period and over an area of approximately $800 \mathrm{~m}^{2}$. All samples were preserved in $96 \%$ ethanol.

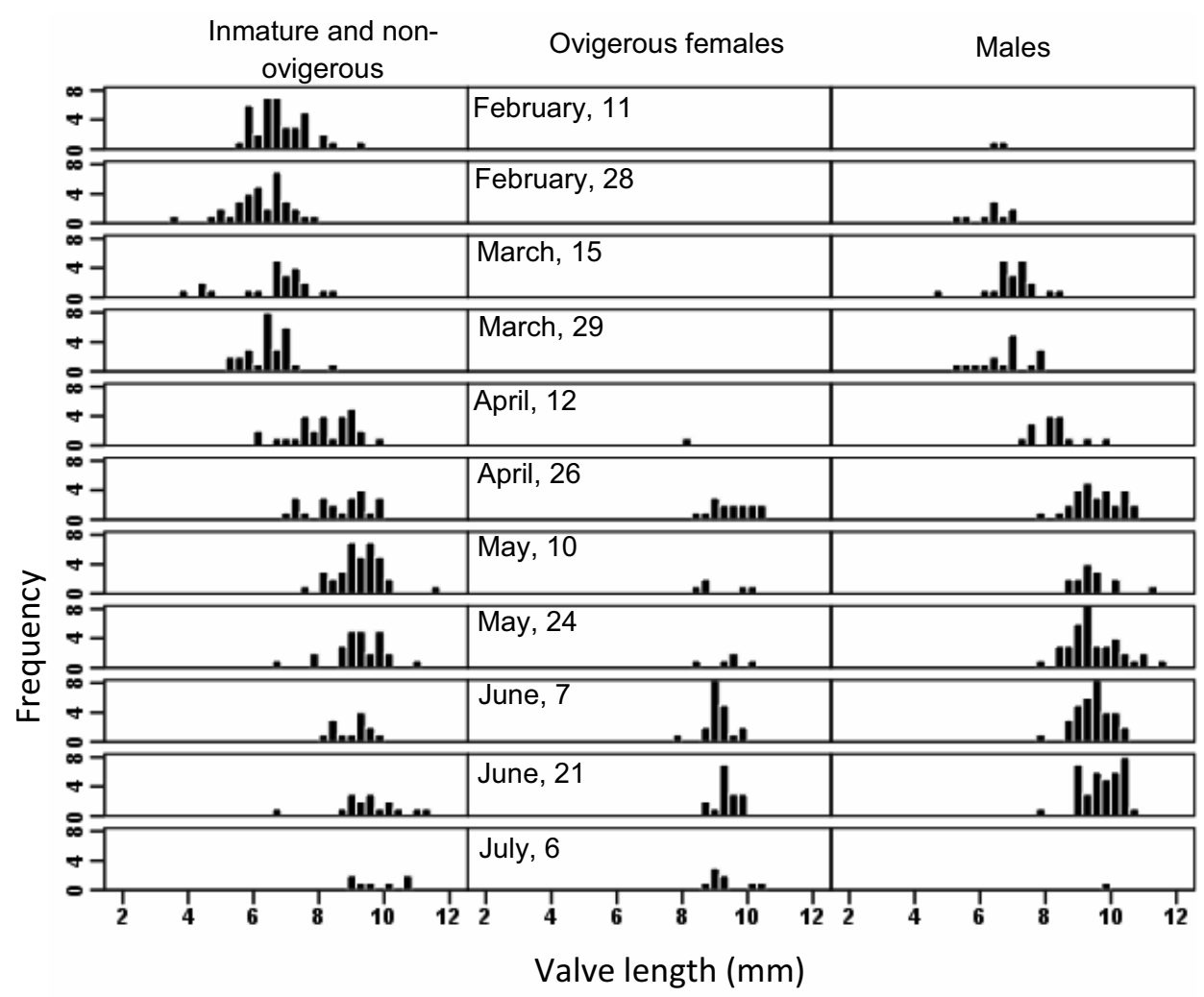

Figure 2. Length-frequency distribution of Cyzicus grubei in La Gitanilla pond from February 11, 2011 to July 6, 2011. Distribución de frecuencias de la longitud de Cyzicus grubei en la laguna de La Gitanilla desde el 11 de febrero hasta el 6 de julio de 2011. 


\section{Laboratory analysis}

In the laboratory, the cyzicids were identified and separated according to sex (Alonso 1996) and ovigerous condition. The animals were grouped into five categories: mature males (specimens with male claspers fully developed, MM); immature males (specimens with male claspers partially developed, IM); ovigerous females (females carrying eggs between their valves, OF); and nonovigerous females (large females that don't carry eggs between their valves, NOF). Females with a valve length of less than $8.21 \mathrm{~mm}$ (the length of the smallest female carrying eggs) were considered immature females (IF).

The following valve measurements were performed on all specimens: valve length (the maximum extent of the valves, VL); valve height (the maximum extent of valves perpendicular to the anterior-posterior axis, $\mathrm{VH}$ ); and the valve length - valve height ratio $(\mathrm{VH} / \mathrm{VL})$. The dimensions were taken with a precision caliper $(0.01 \mathrm{~mm})$. The cyzicids were then grouped in $0.1 \mathrm{~mm}$ size classes for characterisation of the population structure.

Relative growth was determined by using the logarithmic transformation

$$
\ln Y=\ln a+b \cdot \ln X
$$

and the function $Y=a \cdot X^{b}$, where $X$ is the independent variable (VL), $Y$ is the dependent variable $(\mathrm{VH}), " a$ " is the value of $Y$ when $X=0$, and " $b$ " is the slope of the regression line (Lovett \& Felder, 1989). The " $b$ " value represents the rel- ative growth constant $(b=1$ means isometric growth; $b>1$ means positive allometric growth; and $b<1$ means negative allometric growth). The statistical significance of " $b$ " was tested by Student's t-test. An ANCOVA test was run, with sex as covariable, to establish if there were significant differences in relative growth between the samples (male:female; ovigerous female:nonovigerous female), (Zar,1999).

The sex ratio was calculated throughout the study period. A Chi-square $\left(\chi^{2}\right)$ goodness of-fit test was performed to test whether the sex ratios fitted the expected 1:1 relationship. The statistic $\left(\chi^{2}\right)$ was calculated with Yates correction for continuity whenever df $=1$ (Zar, 1999).

Fecundity was estimated by counting the total number of eggs located under each valve. The number of eggs under each valve was compared using an ANOVA test. Finally, a regression analysis was made between the valve length and the total number of eggs.

All tests were performed using the statistical software PAST (Paleontological Statistics Software Package for Education and Data Analysis, Hammer et al., 2001).

\section{RESULTS}

\section{Population structure}

A total of 515 individuals were obtained: 212 males $(41.16 \%)$ and 303 females $(58.84 \%)$. Of

Table 1. Length and height of valves and length to height ratio in Cyzicus grubei in La Gitanilla pond during the study period (S.D., standard deviation; min, minimum value; max, maximum value). Longitud y anchura de las valvas y relación longitud-anchura para Cyzicus grubei en la laguna de La Gitanilla durante el periodo de estudio (S.D., desviación estándar; min, valor mínimo; max, valor máximo).

\begin{tabular}{lcccccc}
\hline & \multicolumn{2}{c}{ Valve length } & \multicolumn{2}{c}{ Valve height } & \multicolumn{2}{c}{ Valve length/valve height } \\
\hline & mean \pm S.D. & min-max & mean \pm S.D. & min-max & mean \pm S.D. & min-max \\
\hline Population $(n=515)$ & $8.45 \pm 1.42$ & $4.63-11.17$ & $5.74 \pm 1.00$ & $3.40-8.44$ & $0.68 \pm 0.01$ & $0.58-0.88$ \\
Male $(n=212)$ & $8.86 \pm 1.29$ & $5.23-11.17$ & $6.04 \pm 0.91$ & $3.40-7.44$ & $0.68 \pm 0.02$ & $0.60-0.77$ \\
Mature male $(n=160)$ & $9.50 \pm 0.64$ & $8.13-11.17$ & $6.48 \pm 0.53$ & $4.92-8.44$ & $0.68 \pm 0.02$ & $0.61-0.75$ \\
Inmature male $(n=52)$ & $6.89 \pm 0.67$ & $5.23-7.97$ & $4.69 \pm 0.54$ & $3.40-5.80$ & $0.68 \pm 0.04$ & $0.60-0.77$ \\
Female $(n=303)$ & $8.15 \pm 1.43$ & $4.63-10.70$ & $5.54 \pm 1.00$ & $3.45-7.55$ & $0.67 \pm 0.03$ & $0.58-0.88$ \\
Inmature female $(n=120)$ & $6.56 \pm 0.70$ & $4.63-7.84$ & $4.44 \pm 0.48$ & $3.45-5.57$ & $0.65 \pm 0.03$ & $0.58-0.88$ \\
Ovigerous female $(n=69)$ & $9.31 \pm 0.50$ & $8.21-10.50$ & $6.33 \pm 0.44$ & $5.56-7.55$ & $0.67 \pm 0.02$ & $0.61-0.73$ \\
Non-ovigerous female $(n=114)$ & $9.13 \pm 0.58$ & $7.94-10.70$ & $6.21 \pm 0.46$ & $5.09-7.26$ & $0.68 \pm 0.02$ & $0.62-0.74$ \\
\hline
\end{tabular}


Table 2. Sex ratio of Cyzicus grubei in La Gitanilla pond from February 11 to July 6, 2011 (M, male; F, female; NOF, nonovigerous female; $\mathrm{OF}$, ovigerous female). Proporción de sexos en Cyzicus grubei en la laguna de La Gitanilla desde el 11 de febrero hasta el 6 de julio de 2011 (M, macho; F, hembra; NOF, hembra no ovígera; OF, hembra ovígera).

\begin{tabular}{cccc}
\hline Date & M:F & M:NOF & M:OF \\
\hline 11.II & 0.05 & 0.05 & - \\
28.II & 0.27 & 0.27 & - \\
15.III & 0.91 & 0.91 & - \\
24.III & 0.59 & 0.59 & - \\
12.IV & 0.52 & 0.54 & 15.00 \\
26.IV & 0.78 & 1.27 & 2.00 \\
10.V & 0.34 & 0.39 & 2.80 \\
24.V & 1.32 & 1.58 & 8.20 \\
7.VI & 1.03 & 2.62 & 1.70 \\
21.VI & 1.16 & 2.31 & 2.31 \\
6.VII & 0.06 & 0.14 & 0.11 \\
Study period & 0.64 & 0.81 & 3.10 \\
\hline
\end{tabular}

the females, 69 were ovigerous $(22.77 \%)$ females, 114 non-ovigerous females $(37.62 \%)$, and 120 were immature females $(39.60 \%)$. Table 1 shows the length of valves, height of valves and length to height ratio of $C$. grubei in La Gitanilla pond.

The results of this study indicate the existence of a single $C$. grubei cohort for the duration of the flooding period in La Gitanilla pond (Fig. 2). Non-ovigerous females and males were present in the pond throughout the study period. However, ovigerous females were present from midApril to early July.

\section{Body size and size of maturity}

Males had valves significantly larger than females $\left(F_{1,513}=32.92, p<0.001\right)$. Ovigerous females did not have valves significantly larger than non-ovigerous females $\left(F_{1,191}=0.5118\right.$, $p=0.4752$, Table 1 ).

Males had valves significantly higher than females $\left(F_{1,513}=33.52, p<0.001\right)$. Ovigerous females did not have valves significantly higher than non-ovigerous females $\left(F_{1,191}=0.3081\right.$, $p=0.5795$, Table 1). No significant differences were found between the valve length/valve height ratios. No significant differences were found between males and females $\left(F_{1,513}=0.661\right.$, $p=0.4166)$ nor between ovigerous and nonovigerous females $\left(F_{1,181}=0.0002, p=0.9869\right)$.

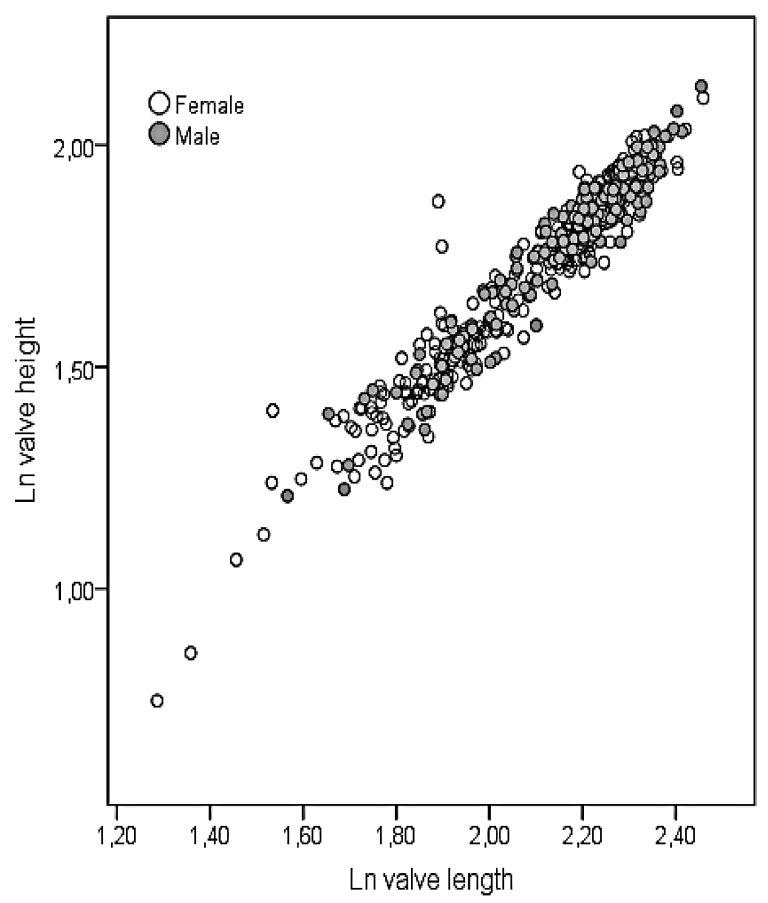

Figure 3. Relationship between the valve length (mm) and valve height $(\mathrm{mm})$ for all individuals in La Gitanilla pond. Relación entre la longitud y anchura de la valva ( $\mathrm{mm}$ ) para toda la población en la laguna de la Gitanilla.

The valve length/valve height ratio was similar in all studied cases (Table 2).

The smallest mature male was $8.13 \mathrm{~mm}$ in VL, while the smallest female carrying eggs was $8.21 \mathrm{~mm}$ in VL.

\section{Relative growth}

Table 3 shows the regression equations obtained in the relative growth analyses. The $\mathrm{VL} \times \mathrm{VH}$ regression plotted to all groups indicates a positive relationship between these variables (Fig. 3). Slopes of regressions of the ln-transformed data showed that there was positive allometric growth in males, and negative allometric growth in females and the whole population. In both sexes, immature samples had a greater growth than adults. No significant differences were detected between slopes of regressions, between males and females (ANCOVA, $F_{1,503}=1.70, p=0.188$ ) nor between non-ovigerous and ovigerous females (ANCOVA, $F_{1,174}=1.60, p=0.689$ ). 


\section{Sex ratio}

Females outnumbered males in winter and early spring (Table 3), and males were more abundant in late spring and early summer. However, the proportion of males to females did not statistically deviate from a $1: 1$ sex ratio $\left(\chi_{1}^{2}=0.1296\right.$, $p=0.7188$ ). Non-ovigerous females were more abundant than males (Table 2), but their proportion did not deviate from a 1:1 sex ratio $\left(\chi_{1}^{2}=0.036, p=0.8443\right)$. Finally, males were more abundant than ovigerous females, except in early July. The proportion of mature male/reproductive female deviated from the 1:1 $\operatorname{sex}$ ratio $\left(\chi_{1}^{2}=4.41, p=0.003\right)$.

\section{Fecundity}

The mean number of eggs by ovigerous female were $574.74 \pm 245.29$ (mean \pm S.D.), ranging from 241 to 1068 eggs/female. There were significant differences between the number of eggs located in both valves $\left(F_{1,52}=33.88 ; p<0.001\right)$. The differences oscillated between $0-33.22 \%$. In $C$. Grubei, the number of eggs is linearly correlated with the valve length of the female $(r=0.8487, p<0.001)$.

\section{DISCUSSION}

\section{Population structure}

Most branchiopod species produce eggs that are resistant to desiccation and, in some cases, such a condition is required before the eggs can hatch. Consequently, there is usually a single generation for each flooding period. This is the case of La Gitanilla pond, where only a single generation was observed from January to July 2011. This concurs with previous observations made by Machado et al. (1999a) and Pérez-Bote et al. (2004) in temporary ponds from the southwestern Iberian Peninsula. However, in other cyzicids, more than one generation has been reported. In Croatia, two cohorts of Cyzicus tetracerus were developed in a single hydroperiod (Popović \& Gottstein-Matoćec, 2006).

Many studies (e.g., Marcus \& Weeks, 1997; Mura et al., 2003; Eitam et al., 2004) support the idea that the environmental parameter that most influences species distribution in temporary waters is the hydroperiod. Mura et al. (2003) demonstrated that Chirocephalus diaphanus (Anostraca) living in a temporary pond presents rapid growth, precocious reproduction and a

Table 3. Result of the regressions analysis for Cyzicus grubei from La Gitanilla (VL, valve length; VH, valve height; $a$ and $b$, constants; allometry $=\mathrm{t}$ test for slope $(b) ; r$, determination coefficient; $t$, statistic values; + , positive allometry; - , negative allometry; *, significant for the $\mathrm{t}-\mathrm{Student}$ test, $\leq 0.05)$. Resultados de los análisis de regresión para Cyzicus grubei en La Gitanilla (VL, longitud de la valva; VH, anchura de la valva; a y b, constantes; alometría = t test para la pendiente (b); $\mathrm{r}$, coeficiente; $\mathrm{t}$, valor estadístico; + , alometría positiva; -, alometría negativa; *, significancia para el test de Student, $\leq 0.05$ ).

\begin{tabular}{|c|c|c|c|c|c|c|}
\hline Sex & $n$ & $\begin{array}{c}\text { Equation } \\
\mathrm{VH}=a \cdot \mathrm{VL}^{b}\end{array}$ & $\begin{array}{l}\text { Linear transformation } \\
\ln \mathrm{VH}=\ln a+b \cdot \ln \mathrm{VL}\end{array}$ & $r$ & $t(b=1)$ & Allometry \\
\hline Population & 515 & $\mathrm{VH}=0.685 \cdot \mathrm{VL}^{0.996}$ & $\ln \mathrm{VH}=-0.379+0.996 \cdot \ln \mathrm{VL}$ & 0.967 & $86.12 *$ & - \\
\hline Male & 212 & $V H=0.681 \cdot \mathrm{VL}^{1.001}$ & $\ln \mathrm{VH}=-0.384+1.001 \cdot \ln \mathrm{VL}$ & 0.964 & $52.83^{*}$ & + \\
\hline Inmature male & 52 & $\mathrm{VH}=0.681 \cdot \mathrm{VL}^{1.004}$ & $\ln \mathrm{VH}=-0.394+1.004 \cdot \ln \mathrm{VL}$ & 0.868 & $12.36^{*}$ & + \\
\hline Mature male & 160 & $\mathrm{VH}=0.354 \cdot \mathrm{VL}^{1.002}$ & $\ln \mathrm{VH}=-0.223+1.002 \cdot \ln \mathrm{VL}$ & 0.862 & $21.14^{*}$ & + \\
\hline Female & 303 & $\mathrm{VH}=0.692 \cdot \mathrm{VL}^{0.992}$ & $\ln \mathrm{VH}=-0.368+0.992 \cdot \ln \mathrm{VL}$ & 0.965 & $64.31 *$ & - \\
\hline Inmature female & 120 & $\mathrm{VH}=0.890 \cdot \mathrm{VL}^{0.986}$ & $\ln \mathrm{VH}=-0.116+0.986 \cdot \ln \mathrm{VL}$ & 0.855 & $17.93 *$ & - \\
\hline Ovigerous female & 69 & $\mathrm{VH}=0.743 \cdot \mathrm{VL}^{0.960}$ & $\ln \mathrm{VH}=-0.297+0.960 \cdot \ln \mathrm{VL}$ & 0.748 & $9.25 *$ & - \\
\hline Non-ovigerous female & 114 & $\mathrm{VH}=0.702 \cdot \mathrm{VL}^{0.964}$ & $\ln \mathrm{VH}=-0.354+0.964 \cdot \ln \mathrm{VL}$ & 0.844 & $16.64 *$ & - \\
\hline
\end{tabular}


short life cycle, whereas populations living in a semipermanent pond showed slow growth, delayed reproduction and a long life cycle. According to our results, the longevity of $C$. grubei in La Gitanilla pond is approximately 130-150 days, and sexual maturity is reached at approximately 75-90 days. In Portugal, the longevity of $C$. grubei was estimated at 120 days (Cancela da Fonseca et al., 2008). In laboratory conditions, Cyzicus californicus lived a mean of 155.7 days and the age at first reproduction was reached at 57.7 days (Helm, 1998). In Croatia, the life cycle of $C$. tetracerus was shorter and was directly related to the hydroperiod (Popović \& Gottstein-Matoćec, 2006). Thus, it seems that the life cycle of cyzicids is initiated when ponds flood and ends when they dry up.

\section{Body size and size of maturity}

Females typically attain a smaller size than males in most crustaceans (da Silva \& Bond, 2008). Sexual size dimorphism may be essential for efficient male performance during pre-copula mate-guarding behaviour in Cyzicus. A larger male-to-female size ratio may allow the male to carry the female more easily during that period, as this has been observed in amphipods (Adams \& Greenwood, 1983). Sexual size dimorphism (carapace length) was observed in $C$. grubei in La Gitanilla pond, where the males attain greater size than females. In south-western Portugal, Machado et al. (1999a) also found males significantly larger than females $(12.9 \mathrm{~mm}$ vs. $12.2 \mathrm{~mm})$. However, in south-western Spain (Pérez-Bote et al., 2004) these differences were not significant. In Lake Cuitzeo (México), Martínez-Pantoja et al. (2002) found that males of Eeocyzicus digueti and Leptestheria compleximanus were also greater than females. However, in Serbia, Popović \& Gottstein-Motoćec (2006) found that $C$. tetracerus males were smaller than females in length and width in one of four ponds studied, and in the remaining ponds males were larger than females. In Italy, the females of $C$. tetracerus were larger than the males (Cottarelli \& Mura, 1983). Morphological variations are not rare in spinicaudatans. Petrov
\& Marinček (1995) observed that a great number of morphological characters change intensively after sexual maturation in Lepthestheria saetosa. Changes continued throughout the entire life cycle, although they were very slow in older specimens. Morphological differences are common in aquatic invertebrates and can be attributed to various factors as food, water temperature or the presence of predators (Green, 2005).

\section{Relative growth}

In this study, males appeared to have a constant relative growth rate of valve height over the entire size-range, whereas females had a higher increase in relative growth from immature to mature. In addition, males had higher growth rates than females. These allometric patterns could be interpreted as a reallocation of energy expenditure after maturation, leading to a variation in growth rate due to competition between developing organs (Nijhout \& Elmen, 1998). No previous studies have been published regarding relative growth in spinicaudatans; however, our results agree with other studies on crustaceans. In female decapods, after maturation energy is needed to produce eggs, and the abdomen could be wide enough to effectively carry all the eggs produced by the female. Consequently, females had broader abdomens than males. In contrast, males allocate a large portion of energy towards cheliped growth and gonad development (Claverie \& Smith, 2009). Female C. grubei carry their eggs between their valves, and thus a similar pattern to that observed in female decapods would be expected in relation to carapace growth (i.e., females had broader abdomens than males). In addition, $C$. grubei shows a complex reproductive behaviour in which males capture and retain females that try to escape (Pérez-Bote, 2010). In these circumstances, large males had competitive advantages in reproduction.

\section{Sex ratio}

Sassaman (1995) indicates that virtually all species of Cyzicidae, Leptestheridae and Lynceidae are characterised by sex ratios near unity, 
thus suggesting obligate sexuality. This author also suggested that the sex ratio based on field samples from natural populations should be viewed with caution, as males and females may display a differential microdistribution in the habitat due to a differential behaviour, ecological preferences, microhabitat uses or differences in survivorship. In our study, females outnumbered males; however, males were more abundant than females in some samples. In south-west Portugal, the sex ratios recorded for $C$. grubei were close to 4:1 (male:female) (Machado et al., 1999a). However, in south-western Spain, females outnumbered males (Pérez-Bote et al., 2004). In Croatia, Popović \& Gottstein-Motoćec (2006) found that the populations of Cyzicus tetracerus, Eoleptestheria ticinensis, and Leptestheria dahalacensis consisted of males and females in an approximately 1:1 sex ratio; however, variations were found between sampling dates and ponds. In our study, the operational sex ratio (OSR), (i.e., the ratio of sexually active males to receptive females) (Correa \& Thiel, 2003) is clearly biased to males. It is widely accepted that the sexual dimorphism featured by many crustaceans is a consequence of a strongly male biased OSR (Correa \& Thiel, 2003). Thus, size differences observed between sexes in La Gitanilla pond may be a consequence of the OSR.

\section{Fecundity}

Fecundity in $C$. grubei was strongly correlated with carapace length. The correlation coefficient (0.84) was similar to those reported for other spinicaudatans: 0.95 for Eulimnadia texana, (Weeks et al. 1997); and 0.87 and 0.88 for Eocyzicus digueti and Lepthesteria compleximanus respectively (Martínez-Pantoja et al. 2002). The number of eggs carried by the female $C$. grubei is also similar to those reported for similar-sized species: E. digueti: 3.5-8.0 mm VL, 1409 eggs; and L. compleximanus: $3.0-8.0 \mathrm{~mm}$ VL, 1180 eggs (Martínez-Pantoja et al., 2002).

Some biological characteristics of $C$. grubei presented in this study are similar to those reported by other studies. Some differences did appear, such as the number of annual generations, which seems to indicate that some of these parameters may be strongly conditioned by environmental factors, such as the hydroperiod. The influence of these factors on the biology of cyzicids should be investigated for more in depth knowledge of these crustaceans.

\section{REFERENCES}

ADAMS, J. \& P. J. GREENWOOD. 1983. Why are males bigger than females in pre-copula pairs of Gammarus pulex? Behavioural Ecology and Sociobiology, 13: 239-241.

ALONSO, M. 1996. Crustacea Branchiopoda. Museo Nacional de Ciencias Naturales-CSIC, Madrid.

BRTEK, J.\& A. THIÉRY. 1995. The geographic distribution of the European branchiopods (Anostraca, Notostraca, Spinicaudata, Laevicaudata). Hydrobiologia, 298: 262-280.

CANCELA DA FONSECA, L., M. CRISTO, M. MACHADO, J. SALA REIS, J., R. ALCÁZAR \& P. BEJA. 2008. Mediterranean temporary ponds in Southern Portugal: key faunal groups as management tools? PanamJAS, 3: 304-320.

CLAVERIE, T. \& I. P. SMITH. 2009. Morphological maturity and allometric growth in the squat lobster Munida rugosa. Journal of the Marine Biological Association of the United Kingdom, 89: 11891194.

CORREA, C. \& M. THIEL. 2003. Population structure and operational sex ratio in the rock shrimp Rhynchocinetes typus (Decapoda: Caridea). Journal of Crustacean Biology, 24: 849-861.

COTTARELLI, V. \& G. MURA. 1983. Anostraci, Notostraci, Concostraci: Guide per il Riconoscimento delle Specie Animali delle Acque Interne Italiane. Consiglio Nazionale delle Ricerche, Verona.

DA SILVA, D. \& G. BOND. 2008. Ecological traits of two sympatric species of Hyalella Smith, 1874 (Crustacea, Amphipoda, Dogielinotidae) from southern Brazil. Acta Oecologica, 33: 36-48.

EITAM, A., L. BLAUSTEIN, K. VAN DAMME, H. J. DUMONT \& K. MARTENS. 2004. Crustacean species richness in temporary pools: relationships with habitat traits. Hydrobiologia, 525: 125-130.

GREEN, J. 2005. Morphological variation of Keratella cochlearis (Gosse) in a backwater of the River Thames. Hydrobiologia, 546: 189-196. 
HAMMER, O., D. HARPER \& P. RYAN. 2001. PAST: Paleontological Statistics Software for Education and Data Analysis. Paleontologia Electronica, 4: 1-9.

HELM, B. P. 1998. Biogeography of eight large branchiopods endemic to California, In: Ecology, Conservation, and Management of Vernal Pool Ecosystems. C. W. Witham, E. T. Bauder, D. Belk, W. R. Ferren \& R. Ornduff (eds): 124-139. California Native Plant Society, Sacramento.

LOVETT, D. L. \& D. L. FELDER. 1989. Application of regression techniques to studies of relative growth in crustaceans. Journal of Crustacean Biology, 9: 529-539.

MACHADO, M., M. CRISTO, J. REIS, L. CANCELA DA FONSECA. 1999a. Biological data on Triops cancriformis mauritanicus (Ghigi, 1921) and Cyzicus grubei (Simon, 1886) -Crustacea, Branchiopoda - in SW Portugal temporary ponds. Limnetica, 16: 1-7.

MACHADO, M., M. CRISTO \& L. CANCELA DA FONSECA. 1999b. Non-cladoceran branchiopod crustaceans from southwest Portugal. I. Occurrence notes. Crustaceana, 72: 591-602.

MARCUS, V. \& S. C. WEEKS. 1997. The effects of pond duration on the life history traits of an ephemeral pond crustacean, Eulimnadia texana. Hydrobiologia, 359: 213-221.

MARTÍNEZ-PANTOJA, M. A., J. ALCOCER \& A. M. MAEDA-MARTÍNEZ. 2002. On the Spinicaudata (Branchiopoda) from Lake Cuitzeo, Michoacán, México: First report of a clam shrimp fishery. Hydrobiologia, 486: 207-213.

MURA, G., G. FANCELLO \& S. DI GIUSEPPE. 2003. Adaptive strategies in populations of Chirocephalus diaphanus (Crustacea, Anostraca) from temporary waters in the Reatine Apennines (Central Italy). Hydrobiologia, 62: 35-40.

NIJHOUT, H. F. \& D. J. ELMEN. 1998. Competition among body parts in the development and evolution of insect morphology. Proceedings of the $\mathrm{Na}$ tional Academy of Sciences, USA, 95: 3685-3689. PÉREZ-BOTE, J. L. 2001. Primera cita de Cyzicus grubei (Simon, 1886) (Spinicaudata, Cyzicidae) en la cuenca del Guadiana. Boletín de la Asociación española de Entomología, 25: 133-134.

PÉREZ-BOTE, J. L. 2004. New records of large branchiopods (Branchiopoda; Anostraca, Notostraca, and Spinicaudata) from Extremadura (south-western Iberian Peninsula). Crustaceana, 77: 871-877.

PÉREZ-BOTE, J. L. 2010. Mating behaviour in Cyzicus grubei (Simon, 1886) (Branchiopoda, Spinicaudata). Crustaceana, 11: 1327-1335.

PÉREZ-BOTE, J. L., A. MUÑOZ, A. J. ROMERO, R. ROSO, E. MÉNDEZ, A. B. MARTÍN \& M. T. LÓPEZ. 2004. Nuevos datos sobre la biología de Cyzicus grubei (Simon, 1886) en la Península Ibérica (Crustacea, Spinicaudata). Boletín de la Asociación española de Entomología, 28: 81-87.

PÉREZ-BOTE, J. L., A. MUÑOZ, J. M. GARCÍA, S. RODRÍGUEZ, A. J. ROMERO, R. 2008. Distribución y abundancia de los huevos de resistencia de Triops cancriformis mauritanicus Ghigi, 1921 y Branchipus cortesi Alonso \& Jaume, 1991 (Crustacea, Branchiopoda) en una laguna temporal del suroeste de la península Ibérica. Limnetica, 27: $57-64$.

PETROV, B. \& M. MARINČEK. 1995. Age-influenced morphological changes in Leptestheria saetosa Mariniček et Petrov, 1992 (Conchostraca, Crustacea). Hydrobiologia, 298: 245-252.

POPOVIĆ, M. \& S. GOTTSTEIN-MATOĆEC. 2006. Biological aspects of the Spinicaudata (Branchiopoda, Diplostraca) in the largest alluvial wetland in Croatia. Crustaceana, 74: 423-440.

PYKE, C. R. 2005. Assessing climate change impacts on vernal pool ecosystems and endemic branchiopods. Ecosystems, 8: 95-105.

SASSAMAN, C. 1995. Sex determination and evolution of unisexuality in the Conchostraca. Hydrobiologia, 298: 45-65.

WEEKS, S. C., V. MARCUS \& S. ALVAREZ. 1997. Notes on the life history of the clam shrimp, Eulimnadia texana. Hydrobiologia, 359: 191-197.

ZAR, J. D. 1999. Biostatistical Analysis. Prentice Hall, New Jersey, USA. 